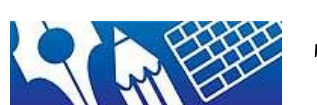

Australasian Association of Writing

Programs

\section{TEXT SPECIAL ISSUES}

Number 60 October 2020

ISSN: 1327-9556 | https://www.textjournal.com.au/

\title{
Letters from Adelaide and Prayagraj
}

\section{Arnis Silvia and Susheel K Sharma}

To cite this article: Silvia, A \& SK Sharma 2020 'Letters from Adelaide and Prayagraj', in J Sarangi \& A Walker (eds) Indian-Australian exchanges through collaborative poetic inquiry, TEXT Special Issue Number 60, TEXT: Journal of writing and writing courses 24, 2 (October): http://www.textjournal.com.au/speciss/issue60/Silvia\&Sharma.pdf 


\title{
University of South Australia and University of Allahabad
}

\author{
Arnis Silvia and Susheel K Sharma
}

\section{Letters from Adelaide and Prayagraj}

\begin{abstract}
:
The collaborative work consisting of corresponding poems between an Adelaide-based poet Arnis Silvia and a Prayagraj-based poet Susheel Sharma deals with anthropological phenomena like identity, ecological awareness and social justice. Taking the geographical background in both resident cities, the six pairs of poems reflect on how both the poets understand the world around them along with its impact on them personally and socially. The poets have employed some principles of duoethnography in their poetic conversations by dialoguing themselves with another self, with another context of culture, tradition, values, histories and meaning-making (Sawyer \& Norris 2012). The authors have attempted to put themselves in someone else's shoes and have tried to see the world through their and others' eyes to better understand the reality(ies) that were portrayed in the poems. The authors have discovered that despite their geographical and cultural differences, they share many similarities in terms of the issues they deal with daily; they struggle with their selves to make sense of the world and they reflect on realities in their surroundings to understand them better.
\end{abstract}

Biographical notes:

Arnis Silvia is an Indonesian-born bilingual poet who is currently undertaking a $\mathrm{PhD}$ programme in Language and Linguistics, University of South Australia. She tutored English for Creative Writing. She writes poetry in both Indonesian and English and has published two books of poems in Indonesian: Titi Kala Mangsa (2017) and Niskala (2019) and one in English, Behind the Closed Door (2017). She has participated in some poetry open mics in Adelaide. She is a member of some literary groups and has published her English poems in Verse Magazine and HLT Magazine.

Dr Susheel Kumar Sharma (b 1962) teaches English at the University of Allahabad, Prayagraj211002, the fourth-oldest university of modern India. Prof. Sharma has three collections of poems in English viz. From the Core Within (1999), The Door is Half Open (2012) and Unwinding Self (2020) to his credit besides several research papers, interviews and book reviews. Some of his poems have been translated into Assamese, French, Lithuanian, Polish, Sanskrit, Serbian, Turkish and Ukrainian languages.

Keywords:

Poetry exchange - duoethnography - ecological awareness - identity - social justice 


\section{Introduction}

The following poems by the two authors based in Adelaide and Prayagraj explore the themes of identity, ecological awareness, and inequality. The settings of the poems occur in some places in Australia (e.g. Adelaide and Sydney) and some places in India (e.g. Mumbai and New Delhi). Some key points portrayed in the poems arise from the reflection of some landmarks in both countries - their history and the values which they convey for both individuals and society. There are six sections presented in this article: the first three sections are poems written by Silvia followed by the responses from Sharma. The last three sections are poems written by Sharma and responded to by Silvia. Each section is concluded with the poets' brief reflections on the poem, splitting into two parts for both poets. Finally, thoughts on this exchange are presented, pinning down some similarities and/or differences in the perspectives.

\section{'Adelaide Arcade' poem and responses}

\section{'Adelaide Arcade' by Arnis Silvia For Karen Pangestu}

There are arms of majestic Carrara marbles

Might be as grand as we dreamt to be: an icon

of longstanding endurance, patience, wisdom

peacefully aged in style and beauty

travelling through the years

of excitement and boredom

This chess-board floor - elegant and humble

capturing steps for more than a hundred years

as we printed our shadows here

these tiles are busy counting our fears

our young souls are wary

we carved our years in anxiety

A throat: a long pageant of timeworn shops

narrates a story of a long back

whose bones were thousands of bricks.

We have bricks too, my dear

We put them on our back

and we call them jobs

a long pageant of our working hours

narrates a story of a long suffering

Before this marvellous fountain of green curved bowls

No one skips their gaze, no one falls 
in love with dreams and shadows

even if beauty costs our backbones

even if patience is just a loan

We wanted what we see

We keep dreaming despite being wary

We will age with our hard-earned wisdom

We will sail the ocean of excitement and boredom.

\section{'The Fountain Square' by Susheel Sharma}

Responding to 'Adelaide Arcade'

The fountain of the city square

Oozing out dreams with coloured water

Under the shades of the tinged lights

Stands erect endearing songs

Celebrating environmental protection.

The white marble around the fountain

has come from Dungri where

The mother is tracing her lost

Arm and the leg in the quarry.

The fountain is no match to

The burning sun that changes

Colours at different hours

Like the marble in different

stomachs of the continents.

The game water and marble played

In the Pandava's palace made Draupadi smile;

The Pandavas were thrilled and enthralled;

Duryodhan was hypnotised and deluded.

Water helps in cutting marbles.

The wishes exuberantly dancing

by the water in the musical fountain

look for the drummers, pianists, bass players and guitarists. Krishna

with his flute strapped to his hip

smiles and smiles. Will he play

or won't he? Radha conjectures.

The guessing game is on. 
Mahabharat is taking shape.

A dice will be thrown

to decide the date

for cutting the marble.

The palace may turn desolate

The fountain may dry up.

Is someone bothered?

Does it matter to me?

\section{Reflections on 'Adelaide Arcade' and 'The Fountain Square'}

\section{Arnis Silvia:}

The architecture of a monumental Adelaide Arcade inspired me to create a reflective poem with the details of shapes, materials and age as the departing point for the metaphors. I put some life-like characters to a building in order to give it a life beyond a building. A building records stories and histories, as do the humans. Personifying Adelaide Arcade has helped me deliver a message that humans too can learn making meaning from architectural works around them. Old buildings, like aged people, could teach some wisdom to the younger minds.

\section{Susheel Sharma:}

Arnis's poem begins with particulars as is clear from the title of the poem. She goes into reflection mode and starts contemplating on the time spent at different places with different people. She moves from one memory to another and talks about the dreams and hopes that had been created together and that have stayed with her (along with her partner/lover). Many of those plans can neither be changed nor destroyed at this stage. They have to be accepted as others are watching them curiously. My two readings of Arnis's poem catapulted me to imagine myself before a musical fountain. The fountain, a metaphor, will not be there without water (soft) and marble (hard) yet they coexist to produce different results in different situations. This generated a lot of ideas and I started meandering through them, pondering over the poor lives of the quarry workers, environmental concerns, impending social conflicts and wars, social injustice and inequalities and remembering stories from the vast repository of anima mundi as well as spiritus mundi.

\section{'Central Market' poem and responses}

\section{'Central Market' by Arnis Silvia}

I wish I were a Central Market

friendly to everyone

intimate to the loyal ones

Like this lady at Stall No.5

with her accent that sounds like mine 
She asks me how my day was

and smiling wide while waving goodbyes

Like this Mohamed at the butchery

He greets me with Salaam

reminds me of home and serenity

I wish my heart

were as warm as this market

as pleasant as croissant at Les Deux Coqs

as nice as the lady's smile at Sun Mi's

as cozy as the laughter at Zuma

They are rebels

for when the weather is intimidating outside

they offer warmth and comfort in the inside

I wish I were persistent as this market

over 150 years of serving

through summer sun and winter wind

through the falling leaves and budding trees

my spring soul is still a baby

everything irritates me

everything becomes allergy

$\mathrm{O}$, market please teach me

How to thrive at my age

with such consistency

I wish I could love like this market

Freely, unconditionally

On the land where visa is a key to its door

I want to be a window opened for everybody

On the land where language tests are a price to stay

I want to be an open book evaluation essay

You can stay for anytime you want to stay

As I am for you

a home when your home is far away.

'Connaught Place' by Susheel Sharma

Responding to 'Central Market'

The Georgian architecture of $\mathrm{CP}$

reminds me of the imperial glory

But I don't wish it to be pulled down

like the disputed structure in Varanasi. 
Hanuman is the oldest inhabitant here; $\mathrm{CP}$ keeps on expanding to make room for The refugees after the Partition and The Tibetans after the Chinese invasion. The inner circle and the outer circle have a centre where people of all hues throng to bargain their wares for love.

It is not averse to the Metro station or to the Heritage Festival or the musical Concert for dissent and blasts; the tricolour Flutters here beckoning the locals.

The white does not oppose the red here; The Jeevan Bharti is no threat to the buildings that are majestic as in Royal Crescent in Bath. Like a lover Enter it, anywhere without a protest. All roads lead to the circular central love.

Driven like the sun by seven horses The Regal cinema leads the people Through seven roads. Here, I bargain for a dress for my daughter, a belt for my Father and a handkerchief to keep me carefree.

The State Emporiums on one side and the shopkeepers lined up like curios on the Queen's Way, rightfully the Janpath, Breathe life into the stately buyers and the popular budget shoppers.

A business centre spreading the batik designs, jootis, mojris, kohlapuris, drums, horns, stamps, coins, postcards, trinkets, necklaces, earrings, books, wall-hangings, carpets; No discrimination between high and low, Indian and foreign, male and female; Each one has to bargain.

I see a world of humanity here Each vying to help each other In their efforts to survive even in the 
competition to hook a customer Hoodwinking is a game that everyone plays and enjoys like the pets do on the return of their masters. Novelty is the key word pasted on tradition. Like a vagabond I have wandered here year after year looking for lessons, home and friends.

\section{Reflections on 'Central Market' and 'Connaught Place'}

\section{Arnis Silvia:}

Adelaide Central Market for me portrays inclusion and a warm welcome; an irony in the middle of a quite exclusive and self-centred city. In a country whose people mostly speak one official language, this market is a door to another world. You could hear many accents here - Chinese, Malay, French, Italian, Spanish and Urdu. The market is also symbolising a resilience (through the changing seasons and economic situation) and equality (where everyone is welcome equally despite the ethnicity, home languages and appearance)

\section{Susheel Sharma:}

Arnis's 'Central Market' is a wish poem as the persona in this poem is wishing to be as useful as the market is to different kinds of people with different aspirations and needs. The poem indirectly talks about the alienation one feels in a foreign land, the longing for love and homeland and expresses a desire for a home away from home. These outer realities lead one to introspect within and one realises how sharp one's edges are and wishes to do them away with to be a part and parcel of one's environs by becoming more useful to the people around.

My poem describes a parallel to Arnis's experience, knowledge and equally important reconciliation. The Connaught Place, a market in New Delhi, represents all sorts of equality, egalitarianism and mingling with dignity. There is no conflict whatsoever between the old and new or the Indian and foreign. Co-existence and not the monopoly of an individual is the principle in the market. The poem, though not didactic in tone and tenor, talks about the value of plurality and acceptance of divergent ways on the life on surface for the survival of humanity.

\section{'Harbour Bridge' poem and responses}

\section{'Harbour Bridge’ by Arnis Silvia}

For Arskal Salim

When morning becomes a mirror

The old autumn puts on lipstick and powder 
Who knows where it goes?

Day is far from ends and it still rolls

Motion: a cost for a life

The beam of pedestrians' steps, passing

Idle musicians moving on their static axis

Everything is rushed, left to the right

Right to the left, above to below, below to above

A wandering mind, trapped

In such a tornado of movement

Can do nothing but follow

A hand that holds her in such enthusiasm

Convincing that today will be special

Puzzled, baffled, bemused

The wandering mind immerses into the motion

That brings her to the lips of the harbour

Fences freshly painted green

And seagulls squawking under warm sunbeam

When water becomes mirror

Harbour Bridge reflects her face on the water

Who knows what she sees?

A man is there on his knees

With a diamond ring he offers a bridge

To come across a soul that makes his rich

Two souls separated by distance

Now being tied in a coexistence

A proposal for a friend of life

To seek for peace, to survive the strife

The wondering heart is now home

No more reason to wander,

No more reason to roam.

'Ram Setu: Remembering Prof APJ Abdul Kalam' by Susheel Sharma Responding to 'Harbour Bridge'

The chain of shoals, the creation

Of nature but the eye-sore of a few

Draws me from Rameswaram and 
Invites me to take a bath in serenity.

Standing at the Bridge of the Sea

The creation of Nala and Neela, I ponder over the past and think

Of Ram, Ravan, Sita and the vanars

The land's connection with Sri Lanka

Unfolds ignorance, jealousy and hatred.

How can one welcome light and love

When thorium outshines the glory of Ram?

The son of a boatman ferrying pilgrims

Diving deep into the calm sea learnt

To catch the huge fish and dig out pearls

Newspapers alone don't supplement income.

Who would believe the son of an Imam

The boat maker, will hold a Veena

And will give wings of fire to India?

Dissatisfied Dean's threat did the trick.

Smiling like the Buddha he mastered

The art to ignite minds catching

Them young in schools and colleges

Removing all heart clots in one go.

The luminous sparks he created

In his valiant vision forged the future

Of the wandering devilish souls trapped

In the middle of tornadoes and earthquakes.

The bachelor to occupy the Bhawan

Coming from uninhibited Dhanushkodi

Conquering Prithvi with spirited Agni acts

On a common code to dispense justice.

If every Sita is to be rescued and saved

Should the People's President, our Ram,

Listen to the pleas of the rapist Dhananjoy?

Does the kidnapper Ravan deserve mercy?

Ram was left alone in serene Ayodhya.

Abdul was deserted by friends in Delhi. 
Defeat corruption is a slogan of the frothy

Waves striking the slippery rocks hard.

Leaving his books, a CD player and a laptop

The soul seeks release of the diamond ring.

Born to blossom, bright Chhotu, surviving the

Strife, renames himself Kalam seeking victory.

Puzzled, baffled, bemused, besotted

I, wandering under the warm sunbeams,

Look at the waves coming from eternity.

Seeking peace Lingam becomes Ramalingam.

It is time to return home; the train is calling;

Interfaith respect and dialogue are waiting;

Is it so difficult to make stones float and

Create a liveable and loveable planet earth?

\section{Reflections on 'Harbour Bridge' and 'Ram Setu'}

\section{Arnis Silvia:}

I see a bridge both as a structure and as a metaphor. Two unconnected lands are tied by the bridge. I wonder how a bridge could be extrapolated to personal connection - two different characters, cultural backgrounds, dreams and aspirations are then being unified by a proposal (metaphorically, a bridge). On the other hand, I also chose Harbour Bridge as a paradox of tranquillity amid the city's hustle bustle. It symbolises our awareness to ourselves, to reconnect with our own mind amid the hectic quotidian life.

\section{Susheel Sharma:}

Arnis's poem led me to view some of the pictures/ images of the Harbour Bridge before it made me spin. This poem of Arnis oscillates between present, past and future. She seems to be more concerned with past which cannot be reclaimed except in terms of memory. The beautiful scene from the bridge is not simply described by Arnis like Wordsworth did in his 'Composed upon Westminster Bridge, September 3, 1802'; Wordsworth has just noted down his impressions while Arnis contemplates.

In my poem I have made use of my experience of visiting Rama Setu or Adam's Bridge. After a brief description of the sight and its mythological importance the poem moves towards the contemporary politics and history. It then concentrates on the life and works of Dr APJ Abdul Kalam, the $11^{\text {th }}$ President of India, who hailed from the same area. An indirect comparison between the vanars who supposedly created the bridge and a man from the same area, who modernised India's defence systems, is made. In both the cases the objective was to attain peace through technology. 


\section{'Akshya Tritya' poem and responses}

\section{'Akshya Tritya' by Susheel Sharma}

The father is waiting for this day

He wants to unburden himself.

The boy is waiting for this day

He wants to bring his love home.

The girl is waiting for this day

She is waiting for a new address.

The jeweller is waiting for the price to go up

The customer is waiting for his turn;

The shops are abuzz;

The doorman is panting

pulling the gate every minute.

Outside a woman is begging

For some money to board the

Bus to reach her village;

She had come to help in the kitchen

at a wedding near the hotel.

The salesgirl says, 'Hurry up, please.

Others are waiting, please.

Please wait for your turn.'

The coffee man is doing rounds.

The manager is quite encouraging;

He shows diamond jewellery

Necklaces, chains, rings one by one;

$\mathrm{He}$ is selective in choosing his clients.

The husband is standing at the back

With a cheque book in his hand

Waiting for his turn to be called out.

This day someone will dance;

Someone will beat the drum;

The GDP may go up on this day;

Even, Budia and Maina are able to

Eat to their fill; Panditji can blow his

Conch shell with full might.

Outside, somebody is asking for votes;

Somebody is urging others to vote.

I shall vote for Akshya Tritya.

\section{'Akshya Tritya 2' by Arnis Silvia}




\author{
Responding to 'Akshya Tritya' \\ Today, the sun and the moon \\ are exalted to their brightest lights \\ today, our luck is tripled \\ whatever planted will live forever \\ whatever bought will always prosper \\ whatever invited will stay no matter. \\ I have been waiting for this day \\ I will give a rebirth to myself \\ I will buy a gold necklace from the jeweller \\ will have it engraved with 'you are enough' \\ will ask Panditji to bless it with his prayers \\ Today, I will plant a Banyan tree \\ and when it grows, I will invite everybody \\ be it God Shiva, be it Buddha \\ under its shade, there will be Havana \\ or if I may \\ I will buy myself and these children a pen \\ we will write our stories \\ that will stay in eternity \\ that will live in the memory \\ Stories that keep us alive \\ even after everyone dies.
}

\title{
Reflections on 'Akshya Tritya' and 'Akshya Tritya 2'
}

\section{Susheel Sharma:}

Akshya Tritya, a festival celebrated across India, is basically a wish for unending prosperity. The poem begins with the anxiety of a father who is waiting for this auspicious day to marry off his daughter (in India, largely, arranged marriages take place and marrying a daughter with all pomp and show and gifting her as many items as possible are a father's sacred duties). Shopping for jewellery is an essential part of preparation for a wedding. The hectic business activity in the shop indicating joy, elation and euphoria (of the rich) associated with the festival, contrasts with those of the poor who struggle to earn their livelihood somehow on this day.

\section{Arnis Silvia:}

I learnt through secondary sources that Akshya Tritya is believed to be a day of 'never-ending prosperity' in which any business happening on that day brings triple luck. I tried to locate something similar to this unique Indian celebration in my Indonesian traditional culture but I could not find anything so precise. If there is anything close enough to Akshya Tritya, it will be 'petungtukukewan' (the calculation of day for buying cattle) in Javanese Indonesian culture which is related to a person's birthday. This day is believed to be the day where the cattle could 
bring more luck and prosperity than does any regular day. My response to the original poem was inspired by my imaginative reflection on how such particular moment could be generating multiplicity of a person's impact on others.

\section{'Rechristening the City' poem and responses}

\section{'Rechristening the City' by Susheel Sharma}

I shall keep you on your toes

You may call me by whatever name you wish to, I am the consciousness

I am the reality, I am the water,

I am the land. Where are the boundaries?

I have followed the rules of expansion

You have to change your rules

You have to change your books

You have to change your atlases.

The rains will fall as ever

The hot winds will blow as ever

Winters will be severe as ever

Men won't dissolve as ever.

The bridges between the roads

And over the mighty rivers

Make the trains move quickly

Over to the other side; people

Use boats as well to connect themselves.

The big fish in the net is making all efforts

To slip into the river again.

It can survive in water only,

And not in the fort, can't you see even this?

Stand up like the Akshya Vat

Against all venoms and poisons.

Creating unbreakable walls

Will write your name on the sands of history.

Deserts need camels not planes.

Don't you understand even this?

Water alone does not make watermelons

They need some pulp, some sugar

Some stripes and colours too.

\section{'The City Which Rewrites Her Name' by Arnis Silvia}

Responding to 'Rechristening the City' 


\section{I am the consciousness}

You people carved your stories on my skin

You whisper your pain into my ears

You write your fear on my eyes

And by the time I need to breathe

I inhale your desperation

And exhale your burden

My body is full of tattoos

Like a temple with too many statues

\section{I am the reality}

This city womb gives birth to too many souls for its arms could hold

Railways claim more victims than guns do

As the trains pass, death is in queue

I am the reality, donc je me suispromis

I would change you

before you could change me

I am the water

And you are just floating

Your outside looks shining

Your inside is empty

I am the water and I am me

You either would sail or you would fail

Go across and make a toss

Because nothing else could this land

Offer you a place to stand.

\section{Reflections on 'Rechristening the City' and 'The City Which Rewrites Her Name'}

\section{Susheel Sharma:}

Naming and renaming, like ebb and flow of the sea-water, indicate the continuous flow of life. It is a universal process related to the (pro/re)gress of civilization. People do not easily accept rechristening as it requires a lot of adaptations. Its implications are far more than perceived. Even the supposedly non-humans are affected by it as they too have feelings. Men have to accustom themselves to their new environs for human history is narrated through spaces, times, buildings, stories, mythologies and books. Renaming affects all this and is affected in turn by them.

Arnis Silvia: 
I interpreted 'Rechristening the City' as a duality of consciousness and power of change. The environment claims its meaning to people's lives and it requires the human/people to have awareness about this nature. The poem also depicts how human beings could be both helpless and hopeful in making changes ecologically. I responded to this poem by addressing to the similar messages. I used textual intervention by taking some lines from the original poem and improvised from there.

\section{'Distancing' poem and responses}

\section{'Distancing' by Susheel Sharma}

When I tried to locate Bombay

in my atlas it gives me

$19.0760^{\circ} \mathrm{N}, 72.8777^{0} \mathrm{E}$

When I look for Mumbai

In my neighbour's it yields

me the same results.

Why is Mumbai far from Bombay then?

The boy from my village

had gone there two years ago;

He has now returned home

with his bandaged arms.

How will he earn his food?

The train to Mumbai is as crowded

as it was when it went to Bombay.

Why did the boy then return to his village?

The atlas does not answer the question.

I silently watch the crowded train

from Mumbai every evening

from my balcony.

\section{'What's in a Name' by Arnis Silvia}

Responding to 'Distancing'

Whenever I mentioned my name without its spelling

to baristas who always wrote me wrongly

'To whom this coffee is for?' they asked

'Arnis' I replied

My cup was named Alice or Annese

neither of whom has ever existed for me

If I were Alice

my skin would be white 
my hair would be blonde

and my body would be tall

my mouth - a tennis ball machine

shooting out balls of swears

to anyone and anything bothering my mind

I would eat pasta instead of rice

I would drink soda instead of tea

I would go to church instead of mosque

I would wear a hairclip not a hijab

And I...would send my mom to an eldercare

Instead of having her under the same roof as I was.

And they would ask me

'what is a name'?

Ask Bombay which changed to Mumbai

Ask Madras which changed to Chennai

How would it be like?

Would I be the same person?

\section{Reflections on 'Distancing' and 'What's in a Name'}

\section{Susheel Sharma:}

The poem is sparked by some real events that took place: the metropolis Bombay was rechristened as Mumbai and certain incidents of violence took place there in which people from north India were targeted. Though the geography of the place remained unchanged its ethos changed. The dreams shown by the metropolis keep on attracting the young people for different reasons and some people wish to have them realised at any cost. Distancing oneself from the scene gives clues to the identities, stories, histories, places and dreams.

\section{Arnis Silvia:}

In reflecting upon 'Distancing', I tried to make a metaphorical link between the change of a city name to the change of a person's name. I understand name as a representation of identity which is an embodiment of our entire self (our characters, history, story, behaviour, dreams, spaces, places). Therefore when a name of a city or a person is changed, their whole identity is altered. I have utilised textual intervention in the last part of my response poem to create the linkage to the original one.

\section{Concluding thoughts}

In our poem-exchange, we made a dialogue in a poetic form about each other's cultural artefacts, historical sites, stories, and finally made our reflection upon our dialectics. We utilised textual intervention (Pope 1995) to resonate the original poem with the other poet's personal experience, values and stories. We created a parallel text to our partner's poetic work. 
We tried to make meaning of our poet-partner's stories, relate them to our own experience, and reproduce this two-way conception in our response poems. We practised a principle in Duoethnography method where we 'untangle our perceptions of our narratives and reform their proportional impact in our life' (Sawyer \& Norris 2012).

As we both learnt from each other's perspectives, we discovered that we had more similarities than differences. We shared perceived experience of co-existence in plural society, alienation and acceptance, social justice and inequalities. This exchange of accounts has contributed to the literature of literary study where poetry was utilised as a tool of Duoethnography to create a space and dialectic for both the poets. Further study could be conducted between poets from more diverse cultures, histories or geographies.

\section{Works cited}

Norris, J, R Sawyer \& D Lund 2012 Duoethnography: Dialogic Methods for Social, Health, and Educational Research, Left Coast Press, Portland: doi: 10.13140/2.1.2184.8644

Pope, R 1995 ‘Textual Intervention', Critical and Creative Strategies for Literary Studies, Routledge, London 